\title{
災害復旧費国庫補助制度の制定に至る史的考察*
}

\author{
A Historical Study on Subsidy Programs by National \\ Budgets for Natural Disasters Restoration Works
}

\author{
市川 紀 - ** \\ By Norikazu ICHIKAWA
}

\begin{abstract}
A Provision on a governmental subsidy for the civil engineering works after natural disasters was enacted on April $21 \mathrm{st}, 1899$ for the first time In Japan enabling the goverment to subsidize prefectural expenditures required for restoration works,

This paper describes the historical process the Naimu-Ministry followed to establish the subsidiary system as well as the state of subsidiary measures at that time before the system was established by use ol documentary records and the materials found by author.

It was also found through calculation of four trial subsidiary cases that the established system imposes much higher butden on the prefectures compared to the formaly adapted subsidiary rate.
\end{abstract}

1.はじぬに

1891 (明治24)年7月、富山県は低気圧の停滞加 ら県下一带が長雨により各河川が増水して、堤防 決壊や破堤により未曾有の災害を被った。この復 旧工事に屿国加県予算規模の 3 倍を上回る補助 金が交付されて河川や道路の土末事業の復旧工事 がなされた。(1.2)

しかし、災害を受けた府県に対して、復旧工事 に必要な實用を国から補助する最初の制度は、 1899 (明治 32) 年 4 月21日付(勅令第260号)で制定 された「災害土木蛽国庫補助規定」である。

この制度は、3月20日付で公布された「災害淘 備基金特別会計法」(法律第81号)に基づく勅令之 して制定されたもので、同年 4 月22日付には、省 令により「災害土木費国庫補助規定施行細則」が 定められた。

本論文では、制度の制定に至るまでの国庫補助
の奏態と内務省で立案を目論んでいた制定の内容 等を文献調査と筆者が発見した当時の史料から明 らかにする。また、立案された制度を適用して補 助金を試算し、各制度の特徵を論述する。

な扔、「災害土木費国莗補助規定施行細則」に 関しては、細則制定以前に内務省から富山県へ災 害視察派遣を通知した文書を筆者が発見したが、 その内容以細則と近似していることから、画者の 比較検討を行なった。

\section{2. 明治期の水害と国庫補助}

$2 \cdot 1)$ 明治期の主な水害

明治期の国や拊県の土木費に関する歳入・歳出予 算の統計資料として、今日では数多くの刊行物があ る。この中で、鉄道を除くわが国の主な土木事業を 所掌した内務省からの刊行物には、1875(明治 8) 年

* keywords:災害 土木行政 国庫補助制度

**正会員 中部九州道路メンテナンス陎）干814 福岡市博多区博多駅前 3 丁目18-28 
から1892(明治25)年守で年報形式の報告書 (3) が、 1887 (明治20)年から1944(昭和19)年までは「内務省 統計報告」(4)がある。

「内務省統計報告」には、自然災害による府県別、 主要河川別の被害額は記録されているが、復旧に要 する国から拊県への補助金等の記録はない。1889 (明治22) 年から1892(明治25) 年まで山「内務省功程 報告」(以下「功程報告」と略称す)に附県別の補助 額が記述されているものの、明治期を通じて災害の 実状と、国から府県、府県加ら町村への補助金等を 記述した記録は見いだせなかった。

表ー 1 は上記の資料と他の資料とを併せて筆者が 作成した、明治期の水害による復旧費と国から附県 へ下付された補助額である。表中、「水害復旧費」 とは当該年度に発生した水害によって被害を受けた 土木施設の復旧するに必要な額である。この中で、 1908 (明治 41) 年、1911(明治44) 年の補助金が復旧費 を上回ったり高額となっているのは、前年度に被害 を受けた復旧費を交付したことによる。

「土木實国費」とは、土木賽国庫金総額から直轄工 事害を差引いた額で、この額は国庫加ら府県等へ交 付された一般の土木費扔よび災害補助金と見なして よい。

同表の水害復旧費が大きな年の要因について山、 気象庁から刊行された資料 ${ }^{(5)}$ により概要を知りう る。

(9)1885(明治18) 年：7月 1 2 日に台風が土佐沖か ら紀伊半島に上陸し、中部地方を綎断して佐渡を 経て樺太へ抜け、全国的に風水害の被害を受けた。 特に、大阪地方岏々礼以前の6月中旬の長雨で淀 川枚方地先が破提し、続いて下流部で決壊した水 は大阪市内に浸水した。さらに、この台風によっ て大阪市内の大半が水害に見舞われた。この洪水 ではこれまで施してきた低水工事の施設はすべて 破壞され、国の治水政策を大きく䎐換せざるを得 なくなった水害であった。

(O) 1889 (明治22) 年：6、7月に全国各地で豪雨災害 が発生し、さらに8月18〜19日の台風は四国東部 から中国地方東部を通過した。四国、近畿地方招 よび愛知、吱阜が大きな被害を受け、和歌山では 死者 1221 人、奈良では250人余であった。 (O) 1893 (明治26)年：10月13〜16日の風水害では中 国、四国、九州地方に大きな被害が生じた。 (9)1896(明治29) 年：7月20 23日に中部以東の東日 本各地で水害が発生し、8、9月に 2 個の台風が

\section{表一1 明治期の洪水等の災害覺と国庫補助金一覧} (作成：市川紀一) 単位：円

\begin{tabular}{|c|c|c|c|c|}
\hline 酉曆 & 阴治 & 水害復旧費 & 災害補助金 & 土木寶国貫 \\
\hline 1882 & 15年 & & 305,500 & 417.522 \\
\hline 1883 & 16年 & & & 577.544 \\
\hline 1884 & 17 年 & & 52,788 & 556,604 \\
\hline 1885 & 18年 & $4,931,097$ & 723.329 & $1,627,125$ \\
\hline 1886 & 19 年 & $2.689,291$ & & $1,499,623$ \\
\hline 887 & 20年 & 629,043 & 282,000 & $1,093,391$ \\
\hline 888 & 21年 & 1,328, & 72,500 & 939,263 \\
\hline 89 & 22 年 & 7,58 & $1,559,551$ & $2.590,804$ \\
\hline 1890 & 233年 & 7,11 & 590. & $2,040,125$ \\
\hline 891 & 24 年 & $3,897,501$ & 1.280 & $4,314,484$ \\
\hline 1892 & 25.年 & 6.366,930 & $3,811,784$ & 4,65 \\
\hline 1893 & 26年 & $19,060,909$ & & 3,88 \\
\hline 894 & 27年 & $4,955,815$ & & 3.64 \\
\hline 895 & 28年 & $2,691,233$ & & $2,725,507$ \\
\hline 8962 & 29年 & $24,381,072$ & {$[7,812,395]$} & $4,059,330$ \\
\hline 897 & 30年 & $10,792,283$ & {$[2,695,294]$} & 6,522 \\
\hline 898 & 31年 & 11.707 .968 & $835,285]$ & 3,680 \\
\hline 899 & 32年 & $10,768,273$ & {$[4,039,772]$} & $4,562,147$ \\
\hline 900 & 33年 & $3,414,894$ & 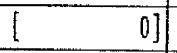 & 2,341 \\
\hline 9013 & 34年 & $2,676,944$ & $284,038]$ & $2,060,466$ \\
\hline $9022^{3}$ & 35年 & 9.977 .575 & $714,196]$ & $2,397,709$ \\
\hline 903 & 36年 & $7,339,998$ & $261,996]$ & 2.765 \\
\hline 804 & 7年 & $7,269,014$ & $632,785]$ & $2,320,780$ \\
\hline 05 & 8年 & $7.059,957$ & $86,740]$ & 1,847 \\
\hline 306 & 9年 & $6,136,392$ & $393,048]$ & $1,881,571$ \\
\hline 07 & 0年 & $20,708,432$ & $744,743]$ & $3,415,223$ \\
\hline 08 & 1年: & $3,202,350$ & {$[4,046,147]$} & 5,256 \\
\hline 109 & 2年 & $6,632,550$ & $686,418]$ & 4,851, \\
\hline 110 & 8 年 & $34,262,725$ & {$[1,584,708]$} & $6,036,763$ \\
\hline 11 & 1年 & $14,525,608$ & {$[5,805,537]$} & $0,140,639$ \\
\hline
\end{tabular}

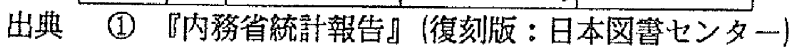

(2) 桨害禣助金は『内務省功程報告』

カギ括弧内数字は『明治大正財政詳覧』(東洋経済新報社) p1

本土に上陸した。最初の台風山8月30〜31日に潮 盰付近に上陸し、大阪、京都の中間を北上して能 登半島へ抜け、紀伊半島の諸罧は大きな被害を受 けた。愛知では死者約9000名という記録が残って いる。9月 6 〜12日の風水害注、九州南端加 国、淡路島西方から能登半島に通り抜けた台風と 秋雨前線によってもたらされたものである。被害 山九州北部、中国地方を除く全国各地で発生し、 関東では利根川、荒川、多摩川の堤防が随所で決 壊し、関東平野は一面の溜流と化した。この被害 は日本の政治の中心東京と経済の中心大阪が大水 害で脅かされる事態となり、高水工事による河川 改修を進めるために、同年12月には「河川法」が 制定された。

(0) 1898 (明治31) 年、1902(明治35) 年はいずれも台風 
によるものである。

(ㅇ) 1910 (明治43) 年：8月には才ホーツク海の高気在 が強く、関東地方はぐずついた天気が続いていた。 そこへ2 個の台風が相次いで襲来し、利根川、荒 川は堤防が寸断され、群馬県では山岳部が崩落災 害を受けた。宮城地方で山北上、阿武隈川が決壊 するるな゙、全国の死者·行方不明者は1383名に達 し、関東地方では1783(天明 3 ) 年以来の大水害と 言われている。この水害で国に臨時治水調查会が 設置され、治水計画を河川改修、砂防、森林治水 の三方面から検討・立案され実施に移された。

\section{$2 \cdot 2)$ 水害の発生要因}

大きな被害をもたらす自然災害には、一時的な地 震や津波によるものもあるが、多雨地帯に属するわ が国の場合は梅雨期、台風期の大雨や長雨で河川汇 濫などによる水害の発生頻度が最も高い。1891(明 治24)年に富山県下を䰚った大洪水の被害視察で当 地を訪れたデ・レーケは、内務省への報告書(8)の中 で河川氾濫による水害発生の要因を次のように揭げ ている。

(1) 河川水源の山地部で忖炭焼きや焼畑のために山 林の伐採が急澈に進み、これにより表土が流失す だけでなく保水力も失われている。また、これら の行為を行なっている人々は、下流域にどれほど の損害を与えているかについて無関心である。

(2)県境部のような丘陵地での道路建設では、河川 の保全を考慮することなく、大量の土砂が投裹さ れている。

(3) 繰り返される洪水によって、上流から大量の土 砂が流下して途中に堆積し、流過できる水量は減 少の一途をたどる。しかし、復旧工事は原形に復 する工事を実施しているため、施工後は同様な規 模の洪水にも耐えることができない。これは費用 の損失である。また、築堤や水制の施工法扝よび 材料などの技術面で改善の余地がある。

(4)河川の各所から灌溉用水を取水しているが、取 水の方法、取水籄所以利用者の利便性だけで実施 されて招り、治水のことは無視している。行政側 が治水、利水の両面から管理、監督すべきである。 川沿に住居を構えている人々(主として農民) は、河 川状態の善し悪しに無関心であるばかりでなく、河 川が氾濫すれば棁金を納めずに済み、場合によっ ては救助資金が与光られる。また、災書復旧工事 で雇用されれば、数日から数週間の仕事が与えら

\section{れ、賃金が支払われる。}

このように、デ・レーケは水源地帯の涵養林の必 要性、理論的根拠を有する河川改修に関する知識不 足、利水に対する規則の必要性なぞ、今日でも示唆 に富む内容の指摘を行なっていた。

また、自然災害は異常気象によってもたらされる が、これは人間の営みがなければ生じない現象とも 言える。すなわち、同様規模の気象条件でも、人間 の営みの規模が拡大し、災害を防ぐ手段がそれに応 じて進歩すれば災害による被害は少なくて旄むこと になる。

本間俊郎はその著 ${ }^{(7)}$ の中で、「徳川300年の間は ほとんど人口の増加は見られなかったが、明治期に なると4000万人弱から明治末には5000万人を笑破す る急激な人口增加が認められ、水田面樻も1883(明 治16)年の256haから明治末年には285haまで開田開 畑された。しかし、食料の自給は急激な人口增加に は追いつかず、明治20年代には米を輸入せざるを得 ないようになった。」と記述している。都市や農地 の開発、急激な人口の增加の影響は、明治期以降の 災害規模もさることながら、被害額を大きくしていっ たと考えられる。

\section{3。災害復旧のための国庫補助の実態と制度}

$3 \cdot 1)$ 明治初期から国会開設まで

1873 (明治 6 ) 年 8 月 2 日付 (大蔵省番外) で「河港 道路修築規則」が布告され、その前文には「……水

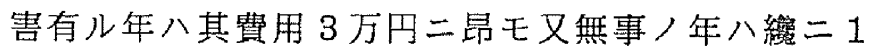
千円ニ出サルモ有シ可シ。而シテ水害八 3 年二一度、 或八 5 年ニ一度可有 9 見積之ヨ平均シタル金額 $习$ 以 テ向フ 5 ヶ年間ノ定額二相立候」と記述されて扣り、 災害が発生した場合は、国が負担することが明記さ れていた。

しかし、1880(日月治13) 年11月5日付(太政官布告 第48号)で布告された「地方税規則」の改正では、 第 3 条に「地方税 河港、道路、堤防、橋梁建築修絴) 費中官費下渡金八来 ル14年度ヨリ廃止トス」とあり、災害復旧費のみな らず通常の土木事業に対しても、従前の国から府県 へ下付されていた下渡金が打ち切られた。

しかし、1882(明治15) 年には22万円余の土木費が 国庫から地方に支弁され、その使途は道路の開削費、 災害復旧費などである。その後も災害復旧費は毎年 の上うに国庫から補助されたが(8)、「功程報告」 には(1)復旧費は地元民力では耐光られない。(2)実地 
の景状と精查の結果などの抽象的な表現が用いられ、 補助金を支出する根拠は明確に示されていない。

\section{2）帝国憲法制定以降}

わが国最初の憲法は1889(明治22) 年 2 月に発布さ れ、翌年11月には国会が初めて開会された。これに より国家予算は国会の議決を経て執行されることに なった。災害が発生した場合の国庫から附県へ補助 する場合は、予備費から支出されたが、当然国会の 承認が必要となる。このため、1890(明治23) 年以降 は苻県から補助金の上申がなされると、土木局から 技師が派遣されて被災地を直接視察し、補助金算定 は「地方税の地租割は国の定めた制限率まで、戸数 割は1戸あたり1円まで增徵し、更に不足する場合 に限って国庫加ら補助する」と(9)、補助金の支出 する根拠扔よび算定方法を明確にした。

1891 (明治24) 年 7 月に富山県下一帯を襲った水害 による国庫補助金上申書は、上記の算式を用いて補 助額を算出している。すなわち、被害総額は1,049， 846円と見積もられ、表一 2 に示すように地租割は 制限率上限 (地租額の1/3) の地租 1 円に付 32 銭 8 厘 まで、戸数割は 1 戸5 銭 6 厘まで地方税を増徵し、 戸数割の 1 戸に付 1 円の不足分67.828円は備荒貯蓄 金から借入して賄うものであった。これにより被害 総額と県が負担する額との差801，354円の国庫補助 を内務大臣宛に上申したが、帝国議会は12月25日に 解散したことから、12月26日付䡃令で先に内定して いた125，000円と併せて843，515円が下付された。

\section{表ー2 1891(明治24) 年の富山県の㒹税} (作成：市川紀一)

\begin{tabular}{|c|c|c|c|c|c|c|c|}
\hline & \multirow{2}{*}{$\begin{array}{l}\text { 地租割 } \\
\text { 戸 数 }\end{array}$} & \multicolumn{2}{|c|}{ 当初 予 算 } & \multicolumn{2}{|c|}{ 追 加 予 算 } & \multicolumn{2}{|c|}{ 年 度 合 計 } \\
\hline & & 金 類 & 賦課率 & 金 額 & 䟼課率 & 金 額 & 䟼課率 \\
\hline & 807,704 & 119,540 & 14銭 8厘 & 145,387 & 18銭 & 264,927 & 32銭 8厘 \\
\hline & 146,982 & 46,446 & 31銭 6 厘 & 35,275 & 24 鋅 & 81,721 & 55 践 6 国 \\
\hline 部 & & 165,986 & & 180.662 & & 346,648 & \\
\hline
\end{tabular}

れている。

\section{表一31889 1892年の復旧貿と国庫補助金} (出典：内務省功程報告)

単位：円

\begin{tabular}{|c|c|c|c|c|}
\hline 県 名 & 西箱 & 災害復旧費 & \multicolumn{2}{|c|}{ 国車補助金悑助率 } \\
\hline 京都附 & 1889 & 273.453 & 84,347 & $31 \%$ \\
\hline 兵渾県 & 1889 & 283.547 & 46,909 & 17 \\
\hline 宮城暻 & 1889 & 343,475 & 105,705 & 31 \\
\hline 和歌山県 & 1889 & 572,667 & 500,000 & 87 \\
\hline 福岡県 & 1889 & 504,974 & 201,990 & 40 \\
\hline 三重県 & 1890 & 358.294 & 118,993 & 33 \\
\hline 曼知県 & 1890 & 295,098 & 98.366 & 33 \\
\hline 埼玉际 & 1890 & 600,162 & 200.054 & 33 \\
\hline 福島䫐 & 1890 & 516.262 & 213.854 & 42 \\
\hline 富山県 & 1891 & $1,054,392$ & 843.515 & BO \\
\hline 福耐県 & 1891 & $1,044,228$ & 575,064 & 55 \\
\hline 基庫景 & 1892 & $1,373,320$ & 824.957 & 60 \\
\hline 風山罝 & 1892 & $2,044,361$ & $1,729,325$ & 85 \\
\hline 徳島県 & 1892 & $1,228,013$ & $1,123,497$ & 92 \\
\hline
\end{tabular}

これらの県への補助額は、次の事例から前述の負 担限度額との差から算出されたと考光られる。1890 (明治23) 年に千葉、茨城、兵愺、岡山、大分の各県は、 復旧のために臨時の費用を徵収した上で、補助金を 上申した。しかし、内務省は地租割または戸数割が 制限に充たないことから申請は却下している。(10)

\section{$3 \cdot 3$ ) 災餘土木基金法 (案)}

1893 (明治26)年11月23日に開会された第 5 回帝国 議会で、政府は「非常準備基金法(案)」を国会に提 案した。この法律は附則を含めて全 6 条の短い法案 (11)で、基金の目的は「非常ノ天災事変ノ為入臨 時ノ支出习要スルトキ一般ノ歳入ヨ以テ支弁シ難キ 場合二於テ之カ補充二充ツルモノトス」とされてい る。

「非常準備基金法案」以、12月12日の第 一読会で特別委員長が委員会での討議内 容を次のように報告した。「天災事変に よって国家予算が不足した場合には、憲 法69条の予備費を流用できるし、な抢不 足の場合は憲法62条に基づいて国債を発

表一 3 は、「功程報告」に記載されている炎害補 助金を下付された附県のうち、災害工事総額30万円 以上に達した府県名と補助額の一覧である。1889 (明治22) 年の台風では、和歌山、奈良、福岡など数多 くの府県が被害を受けたが、和歌山県は土木施設以 外の損害も大きいことから、復旧土木工事費を県民 へ負担させることは不可能であるとして、ほとんど 全額が補助されている。1892(明治25)年の岡山、德 島の両県で蛅被害額が100万円を超え、これらの県 への補助金は、80\%を超える高額の補助金が下付さ
行すればよい。また、基金の原資は毎年の余剩金を 充てるとしているが、大きな金額の余剩金が生じる ような予算を組むこと事態政府は怠慢である」

この結果、第一読会での討議は賛否の両者が登壇 して議諭が戦われたが、最終的には起立者小数で廃 案となっている。

第 5 回議会牥、英国との条約改正を巡って対外硬 六派連合の反対から国会は紛糾し、12月30日に解散 となった。この議会で㳊政府提出の法律案18件のう ち成立した法律は1件のみで、残りはことごとく廃 
案となっている。総選挙後の翌1894(明治27) 年5月 15日開会の第 6 回議会も依然として条約反対派との 対立は続き、5月30日には政府弾刻上奏案が可決さ れたことから、6月 2 日に再び議会は解散した。

「非常染備基金法(案)」が廃案となった背景には、 以上のように政局が不安定な状態であったことも参 酌する必要がある。

高田雪太郎保存文書(12) の中に、写真一1に見る ような「災餘土木基金法」「集県非常土木費国庫補 助法」「地方非常土木費補助法」と命名された災害 補助に関する青焼きの文書がある。これらの文書は、 国会提出する前に地方長官へ諮問したことから高田 が所有していたと考光られ、「災餘土木基金法」第 12 条に「此法律八明治27年 4 月1日ヨリ施行ス」と あることから、第 5 回の議会に提出された「非常準 储基金法(案)」の原案と思慮される。

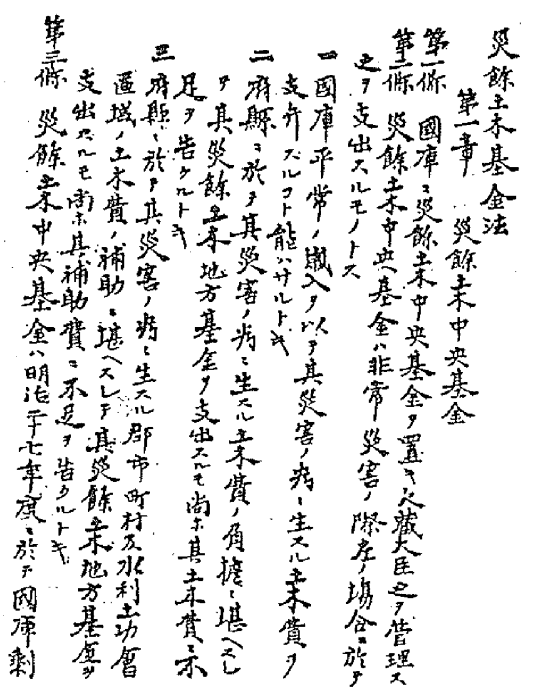

\section{写真一个焱餘土木基金法 原文 (高田家所有)}

「災餘土木基金法」ほか 2 制度の要旨は次のと扝り である。

「災餘土机基金法」は 3 章12条からなり、第 1 章 は「国庫余剩金加ら明治27年度は600万円を繰り入 扎、その後毎年200万、合計 1500 万円を積み立てて 災餘土木中央基金を設けて大蔵大臣が管理し、災害 が生じて国の土木事業や府県の災餘土木地方基金が 不足した場合に支出できる」と規定している。

第 2 章は「災餘土木地方基金」に関する条文で、 「各府県は前年度府県歳出総額の1/15を積み立て、 地方基金として府県知事が管理し、災害のために生 じた府県の土木費の不足や市町村扔よび水利土功会 の災害補助に充てる」と規定されている。な挔、基 金の費用を捻出するために、地方税を增徵すること
はかまわないともされている。

「拊県非常土木費国庫補助法」は全10条からなり、 第 1 条に江「天災事変二因り、破損七ル土木修築， 為メノ国庫ノ補助 定二拠り出願スルコトヨ得」と規定し、以下には府 県の負担限度額の算定方法が明記されている。

算定は第 $4 、 5$ 条に「国へ補助を出願する県は、当 該府罧の地租総額の $2 / 10$ までは府県で負担し、国庫 補助を出願する場合は、さらに残額の $2 / 10$ まで負担 する」とし、但し書きで、拊県負担限度額は地租総 額の1/2までとされている。

第 6 条では、負担額はさらにその残額の1/4を加 算し、この1/4の金額が附県地租総額の $2 / 10$ を超光 るとき㹥、1/5まで減じることができた。

第 $8 、 9$ 条には、出願した府県の土木事業は、内 務大臣が実地に審查して工事の過大や施工する必要 がないと認めた場合は中止を命じることができるこ と。抒よび、補助した工事は内務大臣が監督するな ぞ、中央の権限を強めた規定となっている。

「地方非常土木贅補助法」は全 9 条からなり、市町 村が国または拊県から災害による補助を受ける場合 の規定である。

第 5 回帝国議会に提案された「非常準備基金法 (案)」は、「災餘土木基金法」の地方負担額を具体 的な数字で記述した第 2 章部分は削除されて招り、

「拊県非常土木費国庫補助法」抒よび「地方非常土 木費補助法」も国会に提出されていない。それには 次のような理由が考えられる。(1)議会でも議論され た特別基金の憲法上の位置づけが明確でなかったた め、とりあえず基金の創設を図り、その後に国の負 担を別法で定める予定であった。(2)条約改正問題で 国会は白熱した番議が予想され、大きな負担を府県 に強いた議案は通過の見込みがなかった。

高田の文書には、富山県の予算を基に被害額を想 定した補助金の試算がなされている。この法律が適 用されれば、従来に比べて大幅に県の負担が増加す ることから、各所に修正案が書き込ま机た筆跡が残 されている。これは諮問された富山県は、この法律 制定には必ずしも賛同していないことを同わせるも のである。 
3.4) 非常準備基金法 (案) 廃案から補助規定の制 定まで

第 5 回議会に提案された災害土木費の補助制度は 廃案となったが、第 8 回議会の予算委員会で、災害 を受けた復旧土木蛽の補助制度について、古市公威 土木局長と議員との間に数回にわたる質疑応答のあ と、重野潇次郎詠員が内務大臣に対して今後の方針 を質問した記録がある。(13)大臣は「土木水災の工 事補助金に付ては従来加慎重に慎重を重称て実施 してきたが、補助率については増隇があり不公平を 生じてきた。水災補助に関しては現在法案を提出し て扣り、この案は法律となるか勅令となるかは判断 できないが、今後はこれにより処理したい」と、答 弁している。この答弁した法律を明らかにする文献 は見出せなかったが、井上警関係文書の中に1896 (明治29)年1月 1 日施行「災害土木費国庫補助法案」 1897 (明治30) 年 4 月 1 日施行「災害土木基金法案」 の史料が保存されている。(14)これらの史料から判 眑するに、政府は每年増大する付県への災害補助を 抑制するため、1893(明治26) 年頃から法律の制定を 進めて招り、廃案となったあとも早急に制度を確立 すべく法案整備を目論んでいたことがわかる。

\section{5) 災害土木費国庫補助規定の制定}

わが国最初の災害補助制度である「災害土木費国 車補助規定」(以下「補助規定」と略称す) は、1899 (明治 32) 年 4 月21日付(栜令第160号)で公布された。 この規定は日清戦争で取得した賠償金1000万円を基 金に充当する全 6 条加らな「災害準備基金特別会 計法」(法律第81号)が同年4月20日付で制定され、 同法第 3 条「各附県災害土木費ノ補助二要スル財源 ノ補充、土木補助費二関スル規程八命令ヨ以テ之ヨ 定么」の条文を受けて、勅令で公布されたものであ る。

この法律が審訸された第14回議会は、災害を受け た人々を救援する䍜災救助基金法も同時に提出され ていること、基金の原資が賠償金であることなどか ら、第 5 回議会のような反対意見はなかった。

「補助規定」第 1 条は「府県ノ災害土木費ニシテ其 ノ地租年額ノ十分ノ三ヨ超過スルトキハ、国庫八其 ノ超過額ノ地租額ニ等シキ額二達スル迄八十分ノ四 以内、地租額 $习$ 超過スルトキハ其ノ超過ノ部分二対 シテハ十分ノ五以内 7 補助スルコトヨ得」と、国庫 から負担する割合が規定されている。

第 2 条は「二篭年以上引続キ地租額以上ノ災害土
木蛽习要スル災害アリタル府県ニ対シテハ、前条補 助ノ歩合二依り算出シタル補助額ノ十分ノ三以内 增額スルコトヨ得」と軽減処置が規定されている。

な招、「補助規定」第 4 条には「土木費の範团拈 よび計算方法は内務大臣が定める」とされ、同日付 省令第 9 号で全 14 条の「災害土木費国庫補助規定細 則」が制定された。

\section{6) 災害土木費国庫補助規程}

1911 (明治44) 年 3 月 23 日付 (法律第15号)で制定さ れた法律以「政府八勅令/定ムル所二依り府県災害 土木費ノ一部ヨ補助スルコトヨ得」と、ただ 1 条か らなる非常に短い法律であった。な扔、附則には 「災害集備基金特別会計法八明治 43 年度限り之习廃 止シ、同会計ノ属スル資金八之ヨ治水費資金二編入 ス」と、こ虬までの基金は同日付法律第14号で「河 川の改修、砂防、殖林等の治水事業を推進するため」 の「治水費資金特別会計法」に編入された。

これによって、基金を失った泭県の災害補助に関 しては同年 7 月19日付(栜令第199号)で、全 4 条の 「災害土木費国庫補助規程」(以下「補助規程」と 略称す)が制定された。「補助規程」第 1 条は「附 県災害土木費ニシテ、其ノ拊県ノ地租年額1/79超 過スルトキ八国庫八其ノ超過額二対シ地租額 $1 / 2=$ 超過セサル金額二付テハ4/10以内、地租額 $1 / 27$ 超 過スル金額二付テハ5/10以内 補助スルコト と定められて招り、1899(明治32) 年の規定に比較し て府県の負担が緩和された規程となった。

\section{4. 地租と災害補助制度の比較}

\section{$4 \cdot 1)$ 明治期の地租}

国少ら府県への災害補助金は、1899(明治32)年制 定の法律では国税である地租を、それ以前は府県税 の地租割と戸数割など、いずれの場合も租税をべー スに算出されている。

明治期の租税である「地租」とは、土地に賦課さ れる税で、1897(明治 6) 年に実施された地租改正で 決定された地洒に、一定の税率を乗じて土地所有者 に賦課された国税である。

府県の税目は1873(明治11) 年 7 月22日(布告第19 号)で公布された「地方税規則」で、(1)地租割、

(2)営業税、(3)雑種税、(4)戸数割の4 種と定められた。

「地租割」は「地租」に一定の率を乗した一種の附 加税で、法律等で上限値が定められていた。 地租は1873(明治 6) 年の法律制定時に地価の3/100 
市川 :

\section{垐ー4 明治期における地租括よび地租副}

\begin{tabular}{|c|c|c|c|c|c|c|c|c|c|c|}
\hline 時 & (2) & 相如额 & & & & & & & & \\
\hline $1877(\mathrm{M} 10) \sim 1881(\mathrm{M} 14)$ & & & & & 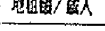 & 坟人 & 相棁額 & 助成/着人 & 地租割 & 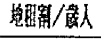 \\
\hline $1882(\mathrm{M} 15) \sim 1886$ & 02,108 & 54,385 & $87.4 \%$ & 41,527 & $67.1 \%$ & & & & & \\
\hline 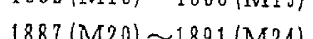 & 13,940 & 63,910 & 84.5 & 43,324 & 57.7 & 19.655 & 17,379 & $88.5 \%$ & 9,354 & $47.6 \%$ \\
\hline 20$) \sim 1891(\mathrm{M} 24)$ & 91,117 & 66.563 & 73.2 & 39,301 & 43.2 & $21,53 \hat{6}$ & 16,347 & 76.9 & 8,439 & 39.7 \\
\hline $1892(\mathrm{M} 25) \sim 1896(\mathrm{M} 29)$ & 105,598 & 71,908 & 70.5 & 38,471 & 38.0 & 27.493 & 18,165 & 66.3 & 9.612 & 35.1 \\
\hline $1897(\mathrm{M} 30) \sim 1901(\mathrm{M} 34)$ & 249,310 & 118,415 & 47.4 & 42.930 & 17.3 & 48,310 & 34,827 & 71,9 & 19,413 & 40,0 \\
\hline 1902 (M35) 1906 (M39) & 363,384 & 205,270 & 56.6 & 63,885 & 17.7 & 52,897 & 41,130 & 78.0 & 21,052 & 39.7 \\
\hline $1907(\mathrm{M} 40) \sim 1911(\mathrm{M} 44)$ & 586,900 & 321,676 & 56.2 & 81,462 & 14.2 & 85,563 & 59,609 & 70.4 & 28,121 & 33,3 \\
\hline
\end{tabular}

註）国の歳入額は一般会計予算歳入総額から余剩金を善引いた額 府県、市町村歳入額は当該年度歳入額から繰越金を差引いた額

とされたが、農民を中心とした全国的な反対運動か ら，1877(明治10)年 1 月には2.5/100に引き下げら れた。地租割の附加率(地租割／地租）の上限値（以 下、上限の附加率を「制限附加率」之略称す)は、 当初は地租の1/3であったが、1878(明治10)年の地 租が軽隇された時点で、1/5に引き下げられた。

表ー4 は明治期を 5 年毎に区分して、地租扔よび 地租割が国や狩県の歳入額に占める割合を示したも のである。同表から、租税の中で地租は大きなり工 イトを占めて拉り、特に、地租割はこの期間を通じ て30\%以上を占める重要な財源であることがわかる。

これらの地租関係の租税は、明治期には何度とな く改定された。図一1は、明治期の国税の地租、府 県税の地租割押よび市町村の地租附加税額(いづれ も決算額)の推移図である。実線は制限附加率(\%) で、折線は附加率（\%)を表わしている。

制限附加率は1880(明治13) 年11月 5 日(太政官布 告第48号)で、府県土木費に対する国からの下渡金 を打切った代りに1/るまで引き上げられた。その後、 1890 (明治23) 年制定の「拊県制」で、1/4までは内
務大臣の許可を得ることなく、知事の権限で課税で きるようになった。1895(明治28)年までは全国平均 値は制限を上回ることはなかったが、1896(明治29) 年の全国に拉よぶ水害が発生した年は制限附加率を 上回る $32.4 \%$ に達し、それ以降は大幅に上回る年が 続いている。

災害補助制度が確立した1899(明治32) 年の制限附 加率は1/2まで引き上げられたが、1904(明治37) 年 からの実績で見た附加率は急澈に下がっている。こ れは、同年に地租が引き上げられたこと、日露戦争 で地方の財政が縮小され、地租割も滅額された結果 生じたものである。

\section{$4 \cdot 2)$ 災害補助制度の比較}

補助制度に扣ける補助金を算出するべースとなる 地租は、明治期を通して何度か改正されている。こ こでは同一条件で国からの補助率を算定し、各時期 の制度の問題点を明らかにする。

表ー5 は試算した一覧表で、試算した条件は次の と拈りである。

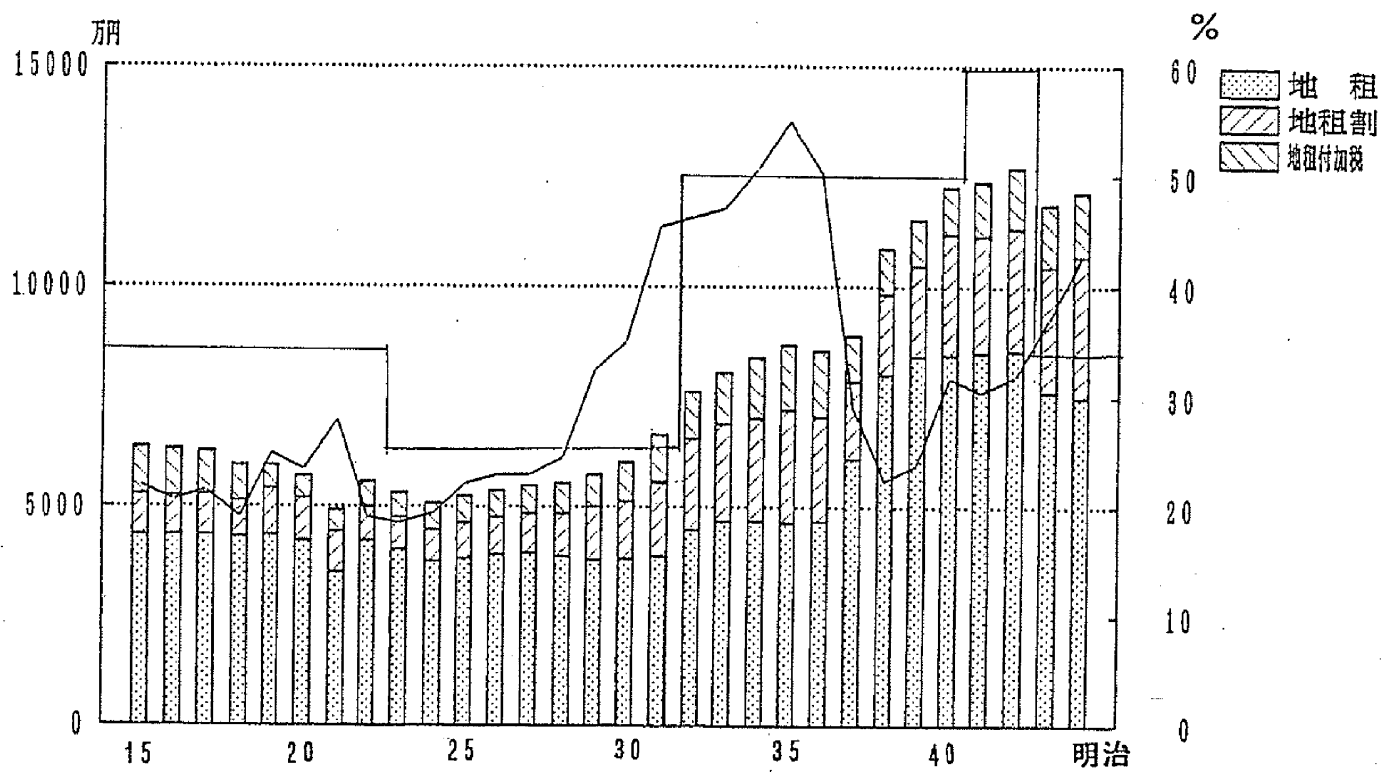

图一 1 団体別地租関䋆税整の推移

(作成：市川紀一) 


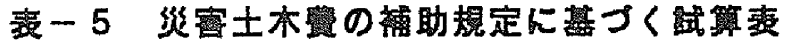

\begin{tabular}{|c|c|c|}
\hline & 被害総額 50 万円の場合 & 被害総額 150 万円の場合 \\
\hline $\begin{array}{l}\text { ㅈ } \\
\text { (1) }\end{array}$ & $\begin{array}{l}\text { *年度当初の地方税 } \\
\text { 地租額 } 800,000 \times 0,22=176,000 \\
\text { 戸数割 } 145,000 \times 0,40=58,000 \\
\text { *地租制限額 } \quad 800,000 \times 1 / 3=266,667 \\
\text { *戸数割賦課 } \quad 145,000 \times 1=145,000 \\
\text { *国庫補助金 }=500,000-(266,667+145,000) \\
\quad+(176,000+58,000)=322,333 \text { 円 } \\
\text { *国庫補助率 } 64,5 \%\end{array}$ & $\begin{array}{l}\text { *年度当初の地方税 } \\
\text { 地租額 } 800,000 \times 0,22=176,000 \\
\text { 戸数割 } 145,000 \times 0,40=58,000 \\
\text { *地租制限額 } 800,000 \times 1 / 3=266,667 \\
\text { *戸数割賦課 } 145,000 \times 1=145,000 \\
\text { *国庫補助金 }=1,500,000-(266,667+145,000) \\
\quad+(176,000+58,000)=1,322,333 \text { 円 } \\
\text { *国庫補助率 } 88,2 \%\end{array}$ \\
\hline $\begin{array}{l}\text { ケ } \\
1 \\
\text { (2) } \\
\text { (2) }\end{array}$ & 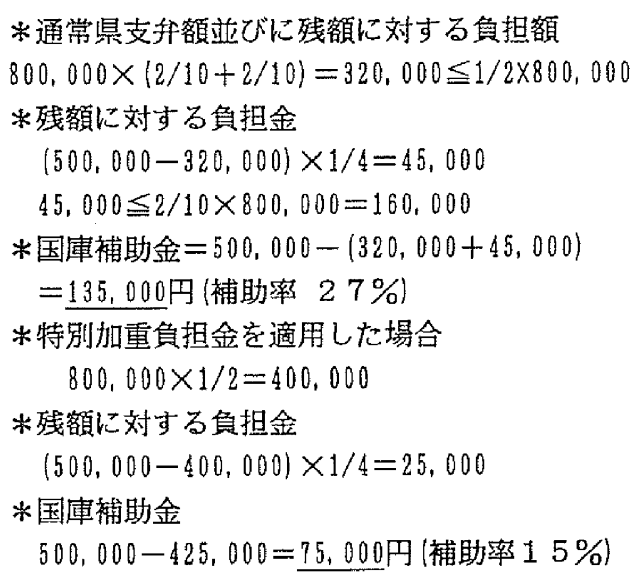 & $\begin{array}{l}\text { *通常県支弁額並びに残額に対する負担額 } \\
\quad 1,500,000 \times 4 / 10=600,000 \geqq 1 / 2 \times 800,000 \\
\quad=400,000 \\
\text { *残額に対する負担金 } \\
\quad(1,500,000-400,000) \times 1 / 4=275,000 \\
275,000 \geqq 2 / 10 \times 800,000=160,000 \\
\text { 故に、 } \\
(1,500,000-400,000) \times 1 / 5=220,000 \\
\text { *国庫補助金 } \\
1,500,000 \text { - }(400,000+220,000) \\
=840,000 \text { (補助率 } 56,0 \%)\end{array}$ \\
\hline $\begin{array}{l}\mathcal{T} \\
1 \\
\text { 지 } \\
\text { (3) }\end{array}$ & $\begin{array}{l}\text { *府県負担限度額地租額 } \\
\quad \text { 地租額 } 1 / 3=800,000 \times 1 / 3=266,667 \\
\text { *国車補助金 } \\
\quad(500,000-266,667) \times 4 / 10=93,334 \text { 円以内 } \\
\text { *国庫補助率 } 18,6 \%\end{array}$ & $\begin{array}{l}\text { *付県負担限度額地租額 } \\
\text { 地租額0 } 1 / 3=800,000 \times 3 / 10=266,667 \\
\text { *国庫補助金 } \\
\quad(800,000-266,667) \times 4 / 10=213,334 \\
(1,500,000-800,000) \times 5 / 10=350,000 \\
213,334+350,000=563,334 \text { 円 } \\
\text { *国庫補助率 } 37,6 \%\end{array}$ \\
\hline $\begin{array}{l}\text { ㅈ } \\
\text { (4) }\end{array}$ & $\begin{array}{l}* \text { 拊県負担限度額地租額 } \\
\text { 地租額の } 1 / 7=800,000 \times 1 / 7=114,286 \\
\text { *国車補助金 } \\
\quad(500,000-114,286) \times 1 / 7=154,286 \text { 円 } \\
\text { *国車補助率 } 30.9 \%\end{array}$ & $\begin{array}{l}\text { *府真負担限度額地租額 } \\
\text { 地租額の } 1 / 7=800,000 \times 1 / 7=114,286 \\
\text { *国庫補助金 } \\
\quad(1 / 2 \times 800,000-114,000) \times 4 / 10=114,400 \\
\quad(1,500,000-1 / 2 \times 800,000) \times 5 / 10=550,000 \\
\quad 114,000+550,000=664,000 \% \\
\text { *国庫補助率 } 44,3 \%\end{array}$ \\
\hline
\end{tabular}

(9)被害総額：50万円拉よび150万円。な招、参考まで に1897(明治30) 年前後の1県当りの全国平均予算 規模は730,000円、東京、大阪などの大都市の予 算は150〜170万円である。このように、被害総額 を大きな金額を仮定した理由は、補助率の緩和規 定を準拠できるようにしたためである。

(ㅇ地租額、戸数割：高田雪太郎の保存文書を参考に、 1893 (明治26) 年の富山県地租額800,000円、戸数 割145，000円とした。
ケース(1)：1890（明治23）年から法律制定までの、国 の補助金算出方法による。

ケース(2)：高田保存文書の「災餘土木基金法」によ る。

ケース(3)：1899(明治32) 年に制定された「災害土木 国庫補助規定」による。

ケース(4)：1911(明治44) 年に改定された「災害土木 国庫補助規程」による。 
試算結果からは次のようなことが言える。

(1) 1890 (明治23) 年から法律制定までの国の補助金 は、すでに附県が年度当初で決定している予算額 から、地租割、戸数割等の租税を定められた限度 額まで増徴して算出された。図一1に示したよう に、明治 20 年代の全国平均地租割は制限附加率ま で到達していないことから、焱害を受けた多くの 狩県は增税可能であったと考光られる。この上、 大きな被害を受けた場合は非常に高い率で補助さ れる制度であった。

(2)廃案となった「災餘土木基金法」や1899(明治32) 年に成案となった制度は、拊県の負担割合が極端 に大きくなっている。

表一 6 は補助制度の成案前後に大きな水害を受 けた富山県の補助額の一覧である。同表から、制 定前の 1896 (明治29) 年、1897(明治30) 年は県負担 と国の補助額の比率は約 $3: 7$ あっあた。これに 対して、制定後の1899(明治32)年は逆転して県は 大きな負担を強いられことがわかる。

富山県は、負担額を全額租税の增徵で賄うこと は不可能であることから、「府県制」第90条を適 用し、債券を発行して不足の費用を補っている。 しかし、打続く水害のために県議会は、補助規定 が制定された直後の1900(明治33) 年 1 月と同年12 月の 2 度にわたり「今回制定の補助制度は九牛一 毛のようなもので、県の経済を疲弊加ら救うこと にはならない」と、厳しい内容の建議書を内務大 臣に提出している。(15)

表一 6 1896 1899年富山県の多害筫と国庫補助金 (出典：富山県政史) 単位：円

\begin{tabular}{|c|c|c|c|c|c|}
\hline 西暦 & 㨔 & 災害復昍費 & 国庫補助金 & 地方負担 & 県賲発行額 \\
\hline 1896 & 29 & $1,666.692$ & $1,161,000$ & 505,692 & 343,269 \\
\hline 1897 & 30 & 936,758 & 700,000 & 236,758 & 329,479 \\
\hline 1899 & 32 & $1,276,270$ & 395,000 & 881,270 & 542,526 \\
\hline
\end{tabular}

(3) 附県への補助率は、1910(明治43) 年に改正され た規程で、若干であるが引上げられた。また、同 年には地租扣よび地租割も引き下げられたことか ら、附県への負担は改善されている。

しかし、明治30年代以降の相次ぐ増税は、国民 に大きな負担を強いたことは、この頃から税金の 滞納者が增大していることからも明らかで(18)、 この上、しばしば洪水などの被害を受けた附県の 住民は、さらに大きな税負担を余儀なくされたと 思虑される。

\section{5 . 災害查定の方法}

災害を受けた附県が国へ復旧費の補助金を申請し た場合、内務省は検查員を現地に派遣して府県が作 成した目論見と現地の災害状況を視察して補助額を 確定した。「功程報告」には拊県ごとの目論見高、 検査高、議会議決高、補助金が記録されているが、 府県の目論見高に対して検査高で差引か机る府県も ある。

高田雪太郎が保存した文書に、1895(明治28)年に 富山県で発生した水害の查察のため、古市公威技監 から德久知事宛に送付された「災害検査内規」と

「災害工事検査員心得」があり、この文書から災害 査定の具体的な内容を知り得る。ここでは、この文 書と1899(明治32) 年 4 月22日(内務省省令第 9 号) で 制定された「災害土木補助費国庫補助規定施行細則」 (以下、「細則」と略称す)と比較, 检討を試みた。

知事宛の文書は、写真一 2 に見るように肩には朱 書きで「秘 第二六四号」と記してあり、高田が保 存していたのは「写し」である。また、通知書面の 冒頭には追而として「検査員に被災地の吏員加同行 を求める場合が多いが、時節がら検查員が要求した 者以外の同行は一切禁止する」と記述され、厳しい 検査であったことが同われる。

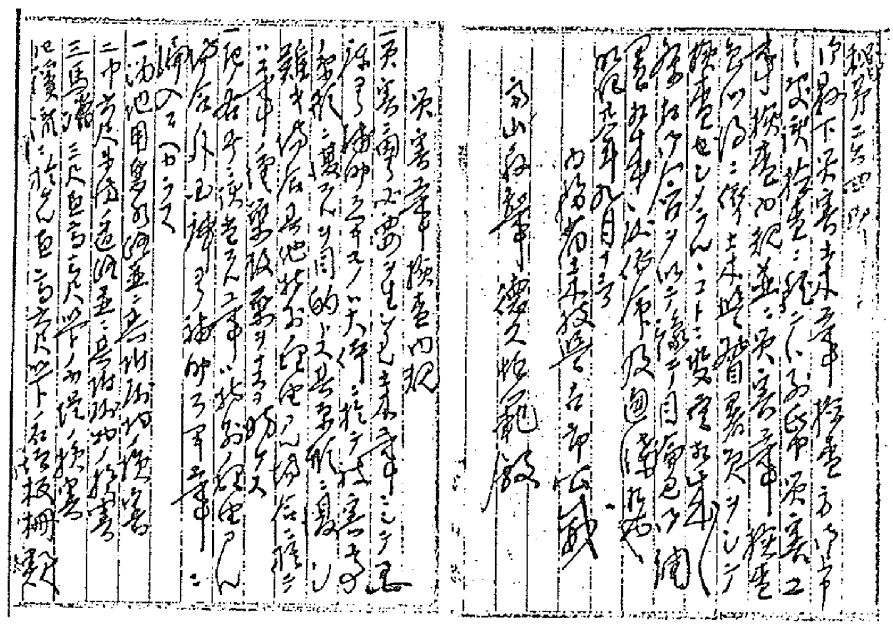

\section{写真一 2 富山県知事宛の通知文(高田家所有)}

この種の文書は、既往の文献等には見いだせなかっ たことから全文を記述する。(句読点は筆者が追加 している!

災害二因テ必要ヨ生シタル土木工事ニシテ、国庫 ヨリ補助スヘキモノ八大体二於テ被害工事ノ原形二 復スルヨ日的トス。其原形二復シ難キ場合、其他特

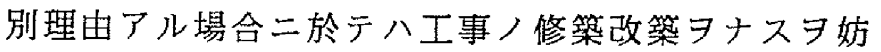
ゲス

一、左ノ各号二該当スル工事八特別理由アル場合ノ 
外、国单ヨリ補助スへキ工事二編入スルヘカラス。

一、溜池用悪水路並二其付属物ノ損害

二、内六尺末満八道路並二其付属物ノ損害

三、馬踏三尺直高三尺以下ノ小瑅ノ損害

四、溪流二於ル直高六尺以下八石垣板䒽類ノ損害

五、河川八埋塞

六、砂防工事ノ損害

七、通行二妨ナキ道路ノ上流若ク八崩土堆積

八、丸太若ク八板ノ投架橋

九、直チ二人家二危害 ヨ及ホス可虑ナキ山崩

十、荁チニ破壊スル慮ナク又他二危害ヨ及ホスへ キ恐ナキ張石、石垣等ノ差狂又八欠損

十一、工種ノ何タルヨ問ハスーケ所ノ工害拾円未

満ノ工事

十二、工種ノ何タルヨ問ハス工事ヨ后年ニ譲リテ

害ナサント認メタルモ，

一、地勢ノ一变シタル為义前二項ノ規定二存ラス特 種ノ計画若クハ処分ナラス必要アリト認ムル八、 別ニ急見习具申シ指揮ヨ乞ツヘシ

\section{災害工重触亘真心得}

一、災害工事ノ検查八縣寶ノ目論見帳习得テ之ヨ行

七検査員、自力ラ目論見タナスヘカラス

二、重要卜認ムル工事八無洩害地习踏查スヘシ、其 他ノ工事卜雖モ目論見二於テ精確 場合八一市町村若ク八同人目論見二係ル区域ノ全 部ヨ踏查スヘシ

三、榆查員八災害工事检查内規二依り計画ノ適否、

破損箇所ノ大量材料、人夫ノ数量及其単価 9 查定 スヘシ

四、人夫責職工貣八縣廳二於テ兼テ定メタル贀格ニ 依り計算スヘシ。土取人夫職八土取場ノ遠近 へ其當否ヨ查定スヘシ

五、材料代價八供給ノ難易 ヨ考工萧テ、縣廳ニ於テ 定メタルモノ二二割乃三割ノ割增ヨ見込コトヨ得 ヘシ

六、特別ノ理由アリテ、災害工事検査内規第一項ノ 增築改築 $\exists$ 要スル場合二第二項各号ノ工事 9 国庫 ヨリ補助スへキ工事二編入スル場合二於テハ、其 理由习摘記シテ特ニ報告スヘシ

七、実地踏查ノ際八目論見主任ノ案内习請求スヘシ この内容と「細則」とを比較した結果、次のよう な事項が明らかとなった。

(1) 国庫補助する対象から除外する工事の内容㤌、 「細則」第 3 条とほぼ同様の内容となっている。
こ和仗、「細則」が制定される以前から「検査員 心得」として、国から補助する工事は内務省内で 決められていた事実を証明するものである。

(2)「検查内規」招よび「細則」とも、国庫補助金を 受ける災害䉪所は原則として原形復旧すること が定められている。1891(明治24) 年の常願寺川の 場合 ${ }^{(1.7)}$ 㤌、多くの堤防が決壊して下流部では決 壊した堤防から川水が全て溢机出てたことから、 第二項の「地勢の一变」したと認められ、検查員 の具申により延長約 $10 \mathrm{~km}$ 亿も扔よぶ河川付替えを 含む大改築工事が可能となったことが理解できる。

(3) 補助対象から除外する工事として12項目を揭げ ている中に砂防工事がある。これは「細則」も同 様に規定されているが、1898(明治31) 年2月2日 (勅令第15号)で制定された「砂防二関スル行政監 督ノ件」に、砂防事業は狩県知事が監督すること が定められ、知事の専決事項であることから除か れたと考えられる。

(4)派遣された検查員はもれなく現地立会いを義務 づけられている。検查期間は1891(明治24)の富山 県の場合、県下一帯に被害が及んだこともあり、 第三監督署の石黒署長は 9 月27日から10月17日の 20 日間、後任の小柴署長は11月18日から23日の5 日間と長期間にわたって詳細な検查定実施してい た。

また、全国に招よび災害が発生した場合には、 内務省江多忙を極めた様子を記述した次のような 記録もある。(18)「災害查定業務は、平常業務を 繰延べ、または停止して、この業務に没頭しなけ ればならなかった。はなはだしいときは、1県内 だけでも1千件以上もあった。また、查定官は引 き続き $3 、 4$ 県の被害附県を超って、1ヶ月以上 にわたって出張することもあった」。

(5)「細則」には、府県と郡、市町村、町村組合、水 利組合、水利土功会等の機関自らが負担する割合 が定められている。しかし、「検査内規」にはこ の規定はない。明治中期ごろは、技師の資格を有 する土木技術者は各府県全てに配風するだけの絶 対数が不足して扣り(19)、災害復旧工事で高度の 技政を要する工事の施行や目論見を作成する能力 は未熟であること、災害復旧工事の場合、県と他 の団体との費用を含む施行区分が規定されていな かった附県も多かったと思慮される。

この推論を証する事例として、高田雪太郎の日 記に次のような記述がある。「災害が発生すれば 
自ら県内全域を視察して目論見を作成し、町村管 理の防波堤の復旧工事は高度な技術を要すること から、県施行としたことに対して議会で紛紏した」 (6) 検查員心得で、「重要卜認ムル」とは損害の程 度加、原形復旧の採否等の技術面加判断するか は判然としない。

\section{6・あとがき}

明治期の土木事業は、1880(明治13) 年11月太政 官布告第48号で、一切の附県土木事業に対して国か らの補助金が打ち切られた。国の基盤整借として重 要な土木事業を国が負担する制度は、山県内務大臣 時代の 1885 (明治18) 年10月に三島通庸土木局長が「 土木䆬準備法案」を作成した(20)。この法案の目的 は「政府の補助制度を確立しなければ、府県の土木 事業は計画的な執行ができないばかりか、苻県議会 運営上も支障をきたす」と建議した。しかし、大蔵 省は予算不足を理由に反対したことから成立に至ら なかった。附罻の土木費に対する国の補助制度の制 定岋、1897(明治30)年3月30日付(法律第37号) の 「国庫ヨリ補助スル公共団体ノ事業二関スル件」ま で待たなければならなかった。

この前年の1896(明治29)年に制定された「河川法」 は、河川の管理、改修抒よびその経賔の負担は原則 として拊県とされたが、広域大規模な河川改修は国 が直轄施行できるとされた。しかし、直轄管理する 河川は附県の負担金が義務づけられ、河川改修事業 の多い拊県にとっては大きな出費となった。(21)

図一2屿全国の土木事業翼を団体別に示したもの である。国庫金は直轄河川の事業費、拊県施行の土 木事業の補助金と災害補助金の合算額であるが、

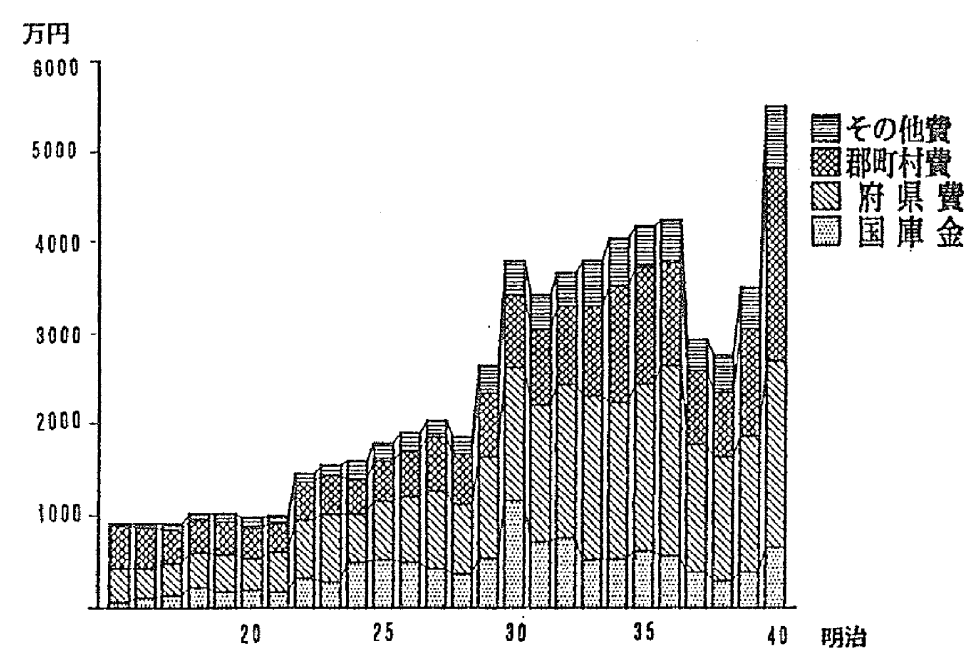

图-2 団别土木費收入の推移（作成：市川紀一)
図の負担割合が小さいことがわかる。これは1878 (明治11) 年に布告された「地方税規則」で定めた「 土木費は地方の負担」の原則が明治期を通して堅持 されたものと解される。それ仂え、災害補助金もこ の原則から外れることなく附県の負担が大幅増とな る制度に至ったものと思慮される。しかも、補助金 算定法を定めた規則は、国会の䒇議を経る必要のな い「栜令」という手段で公布され、国民を代表する 国会の場で議論されることもなかった。

1890 (明治23) 年から補助制度が制定されるまでの 補助金算定方法は、地租割、戸数割を一定の制限值 まで增徵し、不足分を国が補助していた。これによ り大きな被害を受けた附県への国の負担は70〜80\% に達していた。しかし、この算定方法は、各府県の 年度当初予算の租税に左右さ机ることになり不公平 が生じる仕組みであった。これに対して制定された 補助制度は、附県の地租額をべースに算出されたが、 全国に扔よぶ水害が発生した1896(明治29)年の統計 資料 (決算額) ${ }^{(2)}$ 加ら、次のような問題点を指摘す ることができる。

(1) 各府県人口当りの地租額は滋賀県の 1 冈5 5 銭を 最高に、1円を超えている府県は12県に捛上ぶ。 逆に、東京は 34 銭、長踦県は53銭と非常に少額で、 その格差は 5 倍に達している。補助金は地租額だ けをべースに算出すれば、復旧費の負担は人口当 りで考慮すれば府県間で大きな格差が生じること になる。

(2)この年の附加率は、全国平均で制限率1/3を下 回る $28.7 \%$ ある。これを府県別に見れば、最高 は島根県の $50.7 \%$ (一人当り 55 銭)を筆頭に、1１３ を超えている附県は11府県に抢よんで括り、最 少は長崎の $6.6 \%$ (一人当り 5 銭)、静闻は 19.2 \%(一人当り 18 ，7銭)である。

これらの值は、年度途中で追加予算を加えた決 算額であり、年度当初との税額と比較しなけ机ば 一概には带えないが、災害を復旧する人口当りの 負担金は府県間で大きな格差があったと推測され る。

な招、この年に洪水が発生した富山県㹥、全国 で最高額である117万円の補助金が下付されたが、 年度当初の附加率屿 $21.6 \%$ で、決算で33.5\%1 人当り 35 銭)と增額されている。

本論文は1899(明治32)年に制定された「災害土木 費補助規定」までの災害復旧のために国が負担する 補助の実熊と、国が目論んでいた補助制度の問題点 
を論述した。

松浦茂樹は、1896(明治29) 年に成立した「河川法」 は、高水防禦工事を行なうための制度である (23) と 位置づけている。すなわち、明治20年代になって頻 発する水害に対処するため、その後の河川改修計画 は、計画高水量を定めて洪水防御を目的とした統一 的な治水計画が実施さ机、1911(明治44)には第一次 治水計画で65河川が直轄河川に指定された。その後 に河川改修に投じられた費用は洪水が生じた場合の 補助制度と密接に関連するものと考学られるが、こ の研究は本論文の主題とした明治期ではなく、大正 時代以降の調查研究が必要であろう。

\section{謝辞}

本論文の執筆にあたり、土木学会藤井毣男氏、故 竹島勝益氏には文献調查等でご尽力いただいた。

また、熊本大学小林一郎教授からは多くのご助言 を賜った。これらの方々には紙上を借りて感謝申し 上げます。

\section{[参考文献と注歌]}

（1）市川紀一，明治期に扣ける常願寺川の改修工事 (I) 第16回土木史研究会論文集 No16, p190, 1996

（2）市川紀一，明治期に扔ける常願寺川改修工事 第15回土木史研究会論文集№15,pp453４60，1995

(3) 内務省加らの年報は、「年報」「内務省報告書」と名 称が变わり、1886(明治19)年加「「内務省功程報告」 となり、1992 (明治25年) まで発刊された。1893 (明治 26)年6月28日付で廃刊された理由を、大日方純夫は 「同年10月30日付制定の各省官制通則の改正で、報告 書の作成、提出を義務づける条文がなくなったからで ある」と推論されている。

(4) 内務省編, 『内務省統計報告』全52巻 (復刻版) 侏日本図書センター，1988〜1991

(5) 気象庁，『気象百年史』，気象庁, p p 502 507, 1975.3

(6) 上林好之,市川紀一，富山県藸河川の明治24年 7 月 大災害に係るデ・レーケの調查報告，『河川』N0604 $\sim N 0607$, 日本河川協会, $1996.11 \sim 1997.2$

(7) 本間俊郎, 『日本の人口增加の歴史』山海堂、1990.2

(8) 1882 年以降の補助金の実体に関しては次の文献を参考 とした。

(1) 大内兵衛他，『明治前期財政経済史料集成 第五巻』， p 324，『同書第六巻』p25，p373，原書房，1979

(2) 大日方純夫ほか編『内務省年報, 報告書第13巻』 (復刻版), 三一書房, PP15 17 PP47 52, 1984
(3) 井上光貲他編『日本歴史大系 4 近代 I 』 山川出版社, $0595,1987.5$

(9) 大日方純夫ほか編 『内務省年報・報告書第14巻』 (復刻版)，三一書房，p162，p422，1984

(10) 前揭文献(8) p 162

(11) 内閣官報局, 『帝国議会衆議院議事速記録 7 』 (復刻版) p p 36 37, pp165 168, 東京大学出版会, 1985.9

(12) 前揭文献(1) $\mathrm{p} 190$

(13) 明治財政史編算会『明治財政史 第三巻』 pp759 760，1925.11，明治財政史発行所

(14) 国立国会図書館憲政資料室 井上鰲関係文書所蔵

(15) 富山県, 『富山県史 通史編 近代上』, p436, 1981

(16) 海野福寿『日本の歴史(18) 日清, 日露戦争』

集英社, p206, 1992.11

(17) 前揭文献 (2) p 454

(18）大霞会, 『内務省史』(復刻版)，原書房， $068 ， 1980$

(19) 府県別の技師の在職数は『内務留統計報告』に記載さ れている。明治期の技師とは医師や土木以外の工学、

農学系の大学卒業生も含まれて扣り、明治20年代には 技師がゼロの腑県も数多くある。

(20) 伊藤博文編『秘書類箱16 財政資料中巻』(復刻版)， 原書房, $p p 349 \sim 376,1970$

(21) 地方自治百年史編集委員会編筑会,

『地方自治百年史 第 1 巻』，自治制公布百年記念会， $p p 454 \sim 455,1992.2$

(22) 拊県別の人口招よび租税額は次の文献を参考とした。 人口の資料 : 総務庁統計局監修『日本長期統計総覧

第 5 巻』, 日本統計協会, po94 104,1988.5,

租税関係の資料：内閣書記官室記録課，『日本帝国統 計年鑑(復刻版) 第16回』，東京リプリント出版社， pp969 972, 1964.3

(23) 松浦茂樹他，1875 (明治8) 年の堤防法案の審議から 1896 (明治29) 年の河川法成立に至る河川行政の展開, 第14回土木史研究会論文集No14,p74,1994 